\title{
Spontaneous order and social norms. Hayek's theory of socio-cultural evolution ${ }^{1}$
}

\author{
PÉTER GEDEON \\ Professor, Department of Comparative Economics, Corvinus University of Budapest \\ E-mail: pgedeon@uni-corvinus.hu
}

Hayek's theory of socio-cultural evolution is a generalization of his theory on spontaneous market order. Hayek explains both the emergence of market and social institutions serving as a social basis for that order within the framework of a unified evolutionary logic. This logic interprets the emergence and survival of spontaneous order and group-level rules of conduct as an unintended consequence of human action. In order to explain the emergence of social norms exclusively on the basis of methodological individualism, one would have to give up an exclusively evolutionary explanation of these norms. Since Hayek applies the invisiblehand explanation to the investigation of social norms, he combines the position of methodological individualism with functionalist-evolutionary arguments in his analysis. Hayek's theory of socio-cultural evolution represents a theory in the framework of which methodological individualism and functionalism do not crowd out but complement each other.

\section{Keywords:}

JEL-codes: A13, B25, B52, B53.

\section{Introduction}

Hayek's theory of socio-cultural evolution is based on an argument that explains the emergence and functioning of social institutions as an unintended consequence of individual actions. This theory combines explanations relying on methodological individualism with those based on holistic-functional arguments. In the reception of Hayek's theory we find a criticism of Hayek's heterodox evolutionary methodology and its dichotomization. In this essay I would like to show that the attempt at getting rid of the duality of Hayek's methodology in order to maintain the monistic principle of methodological individualism can be achieved at the cost of limiting the range of evolutionary theory in the explanation of social institutions. I find this price too high because I do not think that the theory based on methodological individualism can satisfactorily get rid of the paradox of collective action in the explanation of social norms. At the same time an evolutionary theory based on a heterodox methodology may be able to avoid this paradox by relying on the concept of group-level selection. My argument is structured in the following way: first, I deal with the methodological dualism of Hayek's evolutionary theory that is based on the dual structure of invisible-hand explanations. Then, I describe Hayek's theory of evolution that combines the aggregate mold of the evolutionary argument developed in the theory of the market with the functional mold of explanation that relies on the concept of group-level selection in order to explain the emergence and functioning of rules of conduct and social order. After that I look at the reception of Hayek's theory that dichotomizes its methodology into a contradiction

\footnotetext{
${ }^{1}$ I am grateful to Noémi Péter for her comments on a previous draft of this paper.
} 
between methodological individualism and holism. This is followed by the discussion of Hayek's and Vanberg's theories on the relationship between spontaneous market order and social norms: what are the trade-offs between the two theories, what is gained and what is lost for a theory based exclusively on methodological individualism as opposed to a theory based on a heterodox (dual) methodology. Finally, I conclude.

\section{Invisible-hand explanations}

Hayek's theory on socio-cultural evolution is based on Menger's concept of evolution (See Gray 1984: 16, 33; O'Brien 1994: 348-349). It was Menger who introduced genetic explanation into new economic theory in the debate with the German historical school. Menger argued that it was possible to explain the emergence of economic and social institutions with the analytic concepts of economics. His theory is tied to the principle of methodological individualism, it interprets the emergence of social institutions as the unintended consequence of individual actions. ${ }^{2}$ Menger formed a theory that treated social institutions simultaneously as a social objectivation that transcends individuals and as a result of rational individual choice (see Gedeon 2001; 2004). Individuals pursue their particular interests when they create social mechanisms that coordinate individual actions. Pursuing individual micro motivations may lead to the emergence of social macro structures. This argument creates a close connection between economic and evolutionary theory: macro social institutions are traced back to the micro motivations of self-interested individuals and can be understood as the unintended consequences of individual actions.

Ullmann-Margalit points out that from this theoretical perspective it became possible for Hayek to conceptualize a third - social - sphere of existence beside the natural and the artificial worlds. The realm of Nature is not the result of human action or plan, the world of artifacts is the result of human action and plan, but only the social world is the result of human action but not that of human design. For this reason the explanation of the social sphere of existence is closely related to evolutionary theory. This theory is based on "invisible-hand explanations" (Ullmann-Margalit 1978: 263). Following Menger, Hayek says that "culture is neither natural, nor artificial, neither genetically transmitted nor rationally designed." (Hayek 1979: 155)

However, invisible-hand explanations may be split into two groups, that of aggregate and that of functional-evolutionary molds of explanations, points out Ullmann-Margalit (1978: 282-283). The aggregate mold of explanation presents social order as an unintended, spontaneously emerging consequence of individual choices. Spontaneous aggregation of individual actions leads to social coordination of individual actions. Examples are the emergence and working of market, money and the price system. The functional-evolutionary approach justifies the existence of a social institution with its useful and successful functioning. For example, the endurance of market and money may be justified with that increase in the economic performance of society that is made possible by them. "That is, given that the social pattern or institution to which the first mold of invisible-hand explanations has been successfully applied is functional, the second mold may also be applied to it" (Ullmann-Margalit 1978: 285). ${ }^{3}$

\footnotetext{
${ }^{2}$ Individuals may deliberately create social institutions, but Hayek rejects the argument that the system of social institutions is the result of conscious human action. The systems of social institutions are based on either tradition or the working of impersonal mechanisms and in both cases we may rule out the possibility that they are the outcomes of a conscious human plan. The relationship of the dilemmas of deliberate versus spontaneous emergence of social institutions to Hayek's theory is discussed by Orthmayr $(2002,2004)$.

${ }^{3}$ Gauss emphasizes that functional explanation cannot be causal. Therefore, he says, it cannot be evolutionary
} 
The functional-evolutionary explanation can be applied to the aggregate mold of explanation that interprets the connections of individual actions as a process of coordination, but it is not limited to this. It may be extended to the investigation of those social institutions that cannot be described with the logic of the aggregate mold of explanations. For example, the emergence of social norms may be explained as an unintended consequence of individual actions but cannot be explained as an aggregate result of the actions of individuals who do not intend to establish a social norm. The order of individual actions may emerge not only by following the logic of aggregation of coordination, it may also be created by cooperation. Cooperation means the ex ante mutual adjustment of the intentions of individual actors and assumes collective action. The aggregate mold of explanation cannot grasp the concept of cooperation, since it is built on the assumption that for the emergence of social order it is sufficient to rely on the power of individual micro motivations, particular interests. If invisible-hand explanations are to be extended to the issues of cooperation, then instead of aggregation one has to resort to a functional-evolutionary argument. The functional approach seems to be a possible and a necessary mode of the evolutionary explanation of social norms.

If the aggregate and functional-evolutionary molds of invisible-hand explanation may be connected in the investigation of the spontaneous market order, the question should be asked: "Do they converge upon, complement, or perhaps compete with each other?" (Ullmann-Margalit 1978: 283).

Within the aggregate mold of explanation the analysis of emergence and functioning of economic and social institutions cannot be separated, since the same structural relationship serves as a basis for these two processes. For example, the emergence and the stabilization of money is the result of the same process. Individual actions lead to the emergence of money just because it is in the particular interest of individuals to reduce the transaction costs of exchange, and for this very same reason it is in their interests to maintain the pattern of mediated, indirect exchange. That is why it is possible for economic science to deal with historical processes and to formulate evolutionary arguments. Hayek says that the discovery of that identity is an important achievement of Menger's theory. ${ }^{4}$ The historical explanation can also be a theoretical one just because the two are built on an identical logic.

The point in this which was long not fully understood until at last Carl Menger explained it clearly, was that the problem of the origin or formation and that of the manner of functioning of social institutions was essentially the same: the institutions did develop in a particular way because the co-ordination of the actions of the parts which they secured proved more effective than the alternative institutions with which they had competed and which they had displaced (Hayek 1967: 101).

The investigation of the market led both Menger and Hayek to this insight. Adam Smith applied the metaphor of the invisible hand for characterizing the market as an institution coordinating individual actions in an impersonal way. ${ }^{5}$ Following Adam Smith Hayek asks "[...] how an order formed itself without design [...]" (Hayek 1978: 251). ${ }^{6}$

either, since evolutionary theory must be a causal one (Gauss 2006: 239). However, as we just saw, UllmannMargalit - following Hayek - allows for the existence of a functional-evolutionary mold of explanation. I think it is correct to say that the function of an entity does not explain causally its emergence. However, function becomes important for an evolutionary argument when we want to understand selection and retention.

${ }^{4}$ Hayek approvingly cites Menger: "'Dieses genetische Element ist untrennbar von der Idee theoretischer Wissenschaften” (Hayek 1967: 101).

${ }^{5}$ There are authors who argue that Smith's invisible hand is not a metaphor but a hint at the social role of divine providence. See: Davis 1989, Denis 2001. See also Madarász 2014.

6 " $[. .$.$] an order or regularity could form itself among those actions which none of the acting persons had$ 
Both for Menger and Hayek the theory of socio-cultural evolution is constituted by the generalization of the theory of market. The market order is embedded in social institutions. How can we explain the emergence and retention of social norms that are the necessary social conditions for the existence of the market? Hayek follows Menger when he extends the scope of evolutionary theory to the explanation of those social institutions that are the preconditions of the emergence and functioning of market order. However, in the evolutionary explanation of social institutions Hayek went against Menger when he did not remain within the confines of methodological individualism and emphasized the importance of group selection for evolutionary theory. That is, he also employed functional-evolutionary arguments (see Angner 2002: 711; Beaulier and Prychitko 2006: 63; Haller 2000: 549). As a consequence, Hayek's evolutionary theory pursues two different logics of argumentation, the logic of aggregation that explains the emergence and existence of social institutions within the theoretical framework of methodological individualism and the logic of functional explanation that derives the existence of social institutions from their functions serving the survival of groups of individuals. However, this second explanation is not a causal one. The functional-evolutionary argument does not cover the causal relationships of a given social entity. ${ }^{7}$ The functional explanation of social institutions is compatible both with the assumption of spontaneous emergence of institutions and with the idea of presenting social institutions as the outcomes of deliberate human action (see Ullmann-Margalit 1997: 188189).

Discussing the market as a spontaneous order Hayek follows the aggregate mold of invisible hand explanation but he clearly sees that the logic of aggregation cannot be used for an evolutionary theory extended to the investigation of social institutions constituting the social conditions of spontaneous market order.

"[...] and it is at least conceivable that the formation of a spontaneous order relies entirely on rules that were deliberately made. The spontaneous character of the resulting order must therefore be distinguished from the spontaneous origin of the rules on which it rests, and it is possible that an order which would still have to be described as spontaneous rests on rules which are entirely the result of deliberate design." (Hayek 1973: 45-46)

Hayek acknowledges that an analytical distinction can be made between the logic of the emergence of spontaneous order and that of social norms providing the conditions of that order but this distinction is circumscribed and limited by Hayek's endeavor to keep both aspects of this distinction within the confines of the invisible-hand explanation. I will go back to this problem in this paper.

\section{Market and social evolution}

Since Hayek's theory of socio-cultural evolution is the generalization of the theory of spontaneous market order, understanding the former presumes the knowledge of the latter (Vanberg 1994: 78). ${ }^{8}$ The market for Hayek is a special form of economic coordination. In

\footnotetext{
intended [...]" (Hayek 1967: 97).

7 "It is evident, then, that we are dealing with two quite disparate sets of questions. It follows that the molds of invisible-hand explanation corresponding to them constitute two quite disparate undertakings: the first is concerned with providing a chronicle of (a particular mode of) emergence, the second with establishing raisons d'être" (Ullmann-Margalit 1978: 284).

${ }^{8}$ For the analysis of Hayek's theory of market and the relationship between market and evolutionary theory see Kapás (2002; 2003) and Madarász (2005).
} 
the market the economic activities of individuals are coordinated by the price mechanism (Hayek 1948: 85). The price mechanism allows for the existence of a complex economic system just because it takes off the burden of knowing the totality of economic facts from the individuals. The complexity of economic activities (in the language of classical political economy the division of labor) may grow without overburdening the individuals with information requirements. Through the price mechanism the market is able to utilize efficiently dispersed information residing with individuals.

The most significant fact about this system [the price system - PG] is the economy of knowledge with which it operates, or how little the individual participants need to know in order to be able to take the right action. In abbreviated form, by a kind of symbol, only the most essential information is passed on and passed on only to those concerned. (Hayek 1948: 86)

To say that the price system is a mechanism, a system of telecommunication, is more than a metaphor for Hayek. It means that the price system makes possible the social coordination of individual decisions (Hayek 1948: 87). The market is able to utilize and aggregate the knowledge that the individuals left on their own would not be able to utilize (Hayek 1948: 77-78).

The statement that the market is able to utilize dispersed information possessed by the individuals also means that the market aggregates dispersed information in an impersonal way. That is why the market may process that amount of information that exceeds the capacity of individual human minds. Consequently, no individual can understand the working of the market. If the working of the market was an impersonal - unconscious - mode of social coordination of individuals, the market cannot be the product of conscious individual actions. Individuals cannot consciously create a social institution that is working in an impersonal, that is unconscious way.

[The price mechanism] is not the product of human design and [...] the people guided by it usually do not know why they are made to do what they do. (Hayek 1948: 87)

Therefore, the understanding of the working of market poses a question that should be answered within the framework of an evolutionary theory. The question is how the market as a mechanism of coordination may emerge and work if the individuals do not consciously want to create such an institution and they do not set as a goal to operate the price system? This question can be generalized and asked not only about the market but also about other social institutions.

[...] The problem is precisely how to extend the span of our utilization of resources beyond the span of the control of anyone mind; and, therefore, how to dispense with the need of conscious control and how to provide inducements which will make the individuals do the desirable things without anyone having to tell them what to do.

The problem which we meet here is by no means peculiar to economics but arises in connection with nearly all truly social phenomena, with language and with most of our cultural inheritance, and constitutes really the central theoretical problem of all social science (Hayek 1948: 88).

\section{Rules of conduct versus social order}

For Hayek the analysis of the spontaneous market order has shown that individuals follow 
rules of conduct the nature and function of which they do not and do not have to understand. In this respect the nature of the social order that is coming out of the coordination of rules of individual conduct is not different from the nature of the market. Individuals follow rules in their actions but they do not intend to create that system of social norms that emerges as a result of their actions.

[T] he term 'rule' is used for a statement by which a regularity of the conduct of individuals can be described, irrespective of whether such a rule is 'known' to the individuals in any other sense than that they normally act in accordance with it. (Hayek 1967: 67)

Hayek distinguishes the system of rules of individual actions from the social order of individual actions (Hayek 1967: 66). This distinction has to be made, says Hayek, because it is not obvious that social order, the successful coordination of individual actions, is the result of following general rules embodied in individual actions. There may be general rules that result in social chaos. For instance, individuals may either follow the rule that requires to take away from the others their possessions, that is not to respect private property, or they may follow the rule that requires to respect private property. Following the former rule leads to social chaos, the war of all against all, following the latter leads to social order.

Not every system of rules of individual conduct will produce an overall order of the actions of a group of individuals; and whether a given system of rules of individual conduct will produce an order of actions, and what kind of order, will depend on the circumstances in which the individuals act. (Hayek 1967: 67)

On the basis of the distinction between rules of conduct of individual actions and social order we may understand the working principles of the selection of rules of conduct. Social order or the lack of it that comes about as a result of adhering to rules of conduct feeds back to the existence of rules, only those rules of conduct will survive that result in successful social coordination. Those rules that prove to be unsuccessful in coordinating individual actions will be de-selected and cease to exist. The process of selection takes place on the group level. The particular rules of conduct followed by individuals will survive if they result in successful coordination on the group level.

[T] he genetic (and in a great measure also the cultural) transmission of rules of conduct takes place from individual to individual, while what may be called the natural selection of rules will operate on the basis of the greater or lesser efficiency of the resulting order of the group. (Hayek 1967: 67)

Since those rules of conduct will be selected and stabilized that successfully contribute to the survival of group order, the existence of rules of conduct is tied to the existence of the group. Therefore, individual action is dependent on the existence of group order, it presupposes the existence of this order and at the same time it is creating this order.

It is the resulting overall order of actions but not the regularity of the actions of the separate individuals as such which is important for the preservation of the group; and a certain kind of overall order may in the same manner contribute to the survival of the members of the group whatever the particular rules of individual conduct which bring it about. (Hayek 1967: 68) 
The connection between a special rule of individual action and the social order that emerges as a result of individual rule-following is not the outcome of human intention and plan. A social order survives not because individuals intend to preserve it (Hayek 1967: 68).

It is sufficient that the individuals followed those abstract rules of conduct the universalism of which they had created unconsciously. Social norms are not the result of social contract or social consensus. The different rules of conduct go through a process of group-level selection. General rules of conduct emerge as a result of this selection. Individuals do not understand the meaning of these general rules, but they do not have to. Following these rules the individuals may avoid to try to utilize that amount of information that would overburden their minds. All this means that these rules - just as the market - can be the products of a spontaneous evolutionary process.

$[\mathrm{H}]$ uman intelligence is quite insufficient to comprehend all the details of the complex human society, and it is this inadequacy of our reason to arrange such an order in detail which forces us to be content with abstract rules; and further that no single human intelligence is capable of inventing the most appropriate abstract rules because those rules which have evolved in the process of growth of society embody the experience of many more trials and errors than any individual mind could acquire. (Hayek 1967: 88)

A social order may endure because the rules of conduct resulting in this order will endure. Individuals follow those rules of conduct that survive in the group-level historical process of selection, which proved to be more successful than other sets of rules from an evolutionary perspective.

The individual may have no idea what this overall order is that results from his observing such rules as those concerning kinship and intermarriage, or the succession to property, or which function this overall order serves. Yet all the individuals of the species which exist will behave in that manner because groups of individuals which have thus behaved have displaced those which did not do so. (Hayek 1967: 70)

The rules of individual conduct and the social order that is produced by these rules go through a process of selection led by the success and failure of adaptation to a system of external conditions (Hayek 1967: 68). The rules of conduct will have to change if due to a change in the external conditions the existing rules of conduct fail to bring about social order, that is, if the change of external conditions breaks the connection between the rules of conduct and the social order. In this case individuals may experiment with new rules of conduct. As a consequence of these experiments some of these new rules may be stabilized, those rules that result in a new social order. Therefore changes are started by individual actions. The variety and variability of individual actions constitute the source of variability that serves as a basis for social change. "The simultaneous existence of individuals and groups observing partially different rules provides the opportunity for the selection of the more effective ones." (Hayek 1958: 236)

For Hayek the scheme of evolutionary change is this: change of environment $\rightarrow$ change of individual actions $\rightarrow$ change of social order (Hayek 1967: 71). However, the relationship between individual actions and social order is not unidirectional. Social order is created by rule-following individual actions, but the existing social order decides whether a rule of individual conduct will survive or not. Only those rules of conduct may be stabilized that fit into a given social order, and those individuals may survive in the process of evolution whose rules of conduct prove to be compatible with the existing order of group-level rules. 
These considerations are mainly intended to bring out that systems of rules of conduct will develop as wholes, or that the selection process of evolution will operate on the order as a whole; and that, whether a new rule will, in combination with all the other rules of the group, and in the particular environment in which it exists, increase or decrease the efficiency of the group as a whole, will depend on the order to which such individual conduct leads. (Hayek 1967: 71)

These considerations incite Hayek to connect his evolutionary theory based on the principles of methodological individualism to functional-holistic arguments. Hayek argues that individuals may survive successfully only if their actions successfully contribute to the survival of the group.

This implies a sort of inversion of the relation between cause and effect in the sense that the structures possessing a kind of order will exist because the elements do what is necessary to secure the persistence of that order. The 'final cause' or 'purpose', i.e., the adaptation of the parts to the requirements of the whole, becomes a necessary part of the explanation of why structures of the kind exist: we are bound to explain the fact that the elements behave in a certain way by the circumstance that this sort of conduct is most likely to preserve the whole - on the preservation of which depends the preservation of the individuals, which would therefore not exist if they did not behave in this manner. A 'teleological' explanation is thus entirely in order so long as it does not imply design by a maker but merely the recognition that the kind of structure would not have perpetuated itself if it did not act in a manner likely to produce certain effects, and that it has evolved through those prevailing at each stage who did. (Hayek 1967: 77)

Social order is created by individual actions, but social order cannot be exclusively traced back to individual actions just because it is the unintended consequence of individual actions. The functioning of social order is related to a group-level mechanism of selection that is separated from the individuals, therefore it is working as an independent mechanism of selection. Group-level selection selects among rules of conduct and the group maintains itself in this process. The selection of social rules of conduct takes place on group-level, consequently it is not the result of conscious human action, plan. ${ }^{9}$

\section{The critique of Hayek's theory of evolution}

One of the most important criticisms against Hayek's theory of evolution calls attention to its methodological dualism: Hayek formulated two evolutionary theories that contradict each other, a theory based on methodological individualism and another theory based on functionalist arguments (Vanberg 1994: 85). ${ }^{10}$ This dualism can be eliminated in two different ways. Vanberg thinks that the position of methodological individualism should be pursued consistently, Hodgson argues that a coherent evolutionary theory should give up methodological individualism and should emphasize the primacy of holistic structural

\footnotetext{
9 "Group selection thus does not primarily choose what the individuals recognize as serving their own ends, or what they desire. It will elect customs whose beneficial assistance to the survival of men are not perceived by the individuals. The group thereby becomes dependent for the very survival of its increased numbers on the observance by its members of practices which they cannot rationally justify [...]" (Hayek 1984: 324). "[...] cultural evolution is founded wholly on group selection [...]" (Hayek 1984: 318).

${ }^{10}$ See also Hodgson (1994: 157) and Petsoulas (2001: 64). At the same time Vromen (1995) criticizes Hayek's theory not because it is built on a dualist methodology but because it formulates organicist arguments.
} 
relationships against individual action. ${ }^{11}$

\subsection{Criticism from the position of methodological individualism: arguments against group-level selection}

Vanberg points out that from the position of methodological individualism social changes can only be understood as outcomes of individual choices. However, rational individuals make only decisions that are expected to bring beneficial effects for them. In this conceptual framework it does not make sense to derive social changes from group-level effects, because this latter argument ignores individual motivations connected to change. What is at stake here it is the application of Olson's argument about the paradox of collective action (see Olson 1971). to the problem of group-level selection of rules of conduct. Olson tells us that a beneficial effect requiring collective action may not come about if the members of the group do not shoulder the costs of collective action. But why should they? The members of the group cannot be excluded from the benefits of collective action even if they did not take part in the production of the collective good. It is rational for the individual not to take part in the production of the collective benefit, not to shoulder the costs of collective action, if she cannot be excluded from enjoying these benefits. Only individuals act, the group is not a subject, therefore, due to the existence of free-riding, we cannot derive from group-level benefits the emergence of those individual actions that aim at bringing these benefits about.

A theory of the emergence and persistence of cultural rules has to cope with the problem that group advantage, as such, simply cannot explain why the individuals within the group will actually exhibit such group-beneficial behavioural regularities, given the incentive to free-ride. (Vanberg 1994: 87)

For Vanberg Hayek's argument is inconsistent because it mixes the effects and changes for the individual with those for the group (Vanberg 1994: 83). The incorporation of positive group-level effects into evolutionary theory is false, because from the existence of grouplevel beneficial effects one cannot derive their emergence and retention. If following the functionalist theory we explained change by its positive effects we could not avoid a circular argument and at the same time we would ignore that social mechanism that is the real cause of change, argue Vanberg and Buchanan (1988: 139). If the group-level rule of conduct is assumed not to be the result of conscious individual action, its beneficial effects cannot explain its emergence, since on the basis of this assumption these effects cannot serve as incentives for individual action (see Sugden 1989: 85; Haller 2000: 549; Witt 1994: 185).

[...] Hayek's explanation of social rules in terms of 'group advantage' is subject to the same objection that has been raised against functionalism: in order to provide an explanation at all, a functionalist argument would have to specify a process by which the fact that a social pattern (rule, institution) is advantageous to a group or social system can be reasonably assumed to contribute to the existence and persistence of the pattern (rule, institution) in question. (Vanberg 1994: 88) 12 $^{12}$

The functionalist explanation may demonstrate why a social institution survives in time but it

\footnotetext{
11 “Vanberg and Hodgson offer different solutions to Hayek's presumed inconsistency. Put tersely, Vanberg asserts ontological individualism at the expense of Hayek's idea of group selection, while Hodgson maintains Hayek's idea of group selection at the expense of ontological individualism" (Khalil 1996: 192).

${ }^{12}$ In this aspect Hodgson agrees with Vanberg (see Hodgson 1993: 168). Beaulier and Prychitko (2006: 62) also believe that the way how Hayek combines methodological individualism with funcionalism is illegitim.
} 
must be silent about the process of its emergence, because the beneficial effect created by the institution is not the cause but the consequence of it (See Heath 1992: 34).

Vanberg says that there are two possible explanations for the emergence of a rule bringing about positive group-level effects. Either we assume that the individual members of the group recognize the positive consequences of the rule and establish this rule through individual or collective action, or we may think that there exists a group-level feedback mechanism that will bring about the group-level positive effect independently from the individual actions. None of these propositions are compatible with Hayek's concept of spontaneous order. The first proposition traces back the emergence of group-level rules of conduct to human design, to deliberate individual choice and therefore contradicts to the concept of spontaneous order, the second proposition allows to derive the group-level rule as an unintended consequence of individual actions but does not allow to connect the emergence of these rules to individual choice, interests, incentives. If we accept the second proposition, we are obliged to explain the existence of group-level rules with holistic arguments and have to give up the principle of methodological individualism.

The contradictory character of Hayek's theory of evolution becomes an important problem if the holistic-functionalist argument does not have a real contribution to the theory of socio-cultural evolution. That is exactly what Vanberg says, he thinks that for the theory of evolution that builds on the notion of unintended consequences of individual action, that is builds on the concept of spontaneous order, it is necessary and sufficient to trace back social changes to individual choices (Vanberg 1994: 84-85). ${ }^{13}$ In other words, Vanberg wants to limit the theory of evolution to the aggregate mold of explanation and wants to expel the holistic-functionalist explanation from theory just because it does not stand on the basis of methodological individualism.

\subsection{Criticism from the position of functionalist-holistic theory: arguments in favor of group-level selection}

Hodgson, similarly to Vanberg, points out that in Hayek's theory of evolution there is a tension between the concept of rationality based on methodological individualism and the concept of group-level rationality based on a holistic-functional theory. The two concepts cannot be reconciled.

On the one hand, social evolution can be treated as a group-level selective process of social institutions. This approach drops the analysis of intentionality, the issues of rational individual action and choice, says Hodgson. If we tie the evolutionary survival of individual characteristics and dispositions to the level of social institutions, we will have to give up the assumptions of methodological individualism that are based on the central role individual rational choice. On the other hand, if we think that individual choices determine the process of social evolution, we have to discount the role of social rules and institutions in this process (Hodgson 1993: 157-158).

While Vanberg detaches the issues of the emergence and retention of group-level rules from evolutionary theory in defense of methodological individualism, Hodgson detaches the issues of emergence of group-level rules from methodological individualism in defense of evolutionary theory. For Hodgson the evolutionary explanation of group-level rules is incompatible with methodological individualism. Both authors share the assumption about the dichotomy of methodological individualism and holistic functionalism, they only differ in the way how to resolve this dichotomy. On the basis of methodological

${ }^{13}$ A similar argument can be found in Petsoulas (2001: 64). 
individualism Vanberg proposes the limitation of evolutionary explanation, while on the basis of holism Hodgson proposes the limitation of methodological individualism and the extension of evolutionary approach to the emergence and existence of social norms.

Thus there is an inconsistency in Hayek's work between, on the one hand, the ideas emanating from his individualist roots, and, on the other, his growing commitment to an evolutionary perspective. In an evolutionary context, methodological individualism has to be either redefined or abandoned. (Hodgson 1993: 157)

Hodgson argues that the mechanism of group-level changes cannot be found on the level of individual action, since social selection operates beyond the individuals in the form of grouplevel pressure. That is the solution for the paradox of collective action, the issues of freeriding. We should not trace back the emergence of social norms to the incentives of individual action, because these incentives are predetermined by the pressure of group-level norms.

Cultural transmission is more collective and conformist than genetic transmission. As Robert Boyd and Peter Richerson have shown, conformism provides a compensating mechanism to overcome the free-rider problem. Consequently, the potential free rider is under strong pressure not to free-ride but to conform to the group. The different nature of the transmission process establishes a strong case for cultural group selection. (Hodgson 1993: 173)

Hodgson criticizes Hayek's theory of evolution for its attachment to methodological individualism that prevents this theory from finding the right solution to the problem of collective action and group-level selection. Vanberg says that Hayek's evolutionary theory should have remained within the confines of methodological individualism, Hodgson resents that Hayek's theory of evolution was not able to move successfully beyond methodological individualism.

These criticisms that dichotomize Hayek's heterodox methodological approach for the theory of socio-cultural evolution are closely connected to the way how one looks at the relationship between the market and social norms.

\section{Spontaneous market order and social norms}

Hayek does not deal with the issues of collective action in his evolutionary theory of spontaneous order, because he does not have to. His question is whether individuals, following exclusively their own interests, can create a social order that makes them better off than the previous social order? The concept of spontaneous order is the answer to the question: the spontaneous market order has emerged and maintains itself as an unintended consequence of rational individual actions. Individuals are able to establish market coordination simply by following their individual interests. However, they do not intend to design the market order. Individual actions are motivated by individual utilities, costs and benefits. Still, by following their particular interests individuals will also create money and the price system because it reduces their individual transaction costs. Therefore the emergence and functioning of the spontaneous market order can be described by the logic of aggregation. The spontaneous market order is a collective good for individuals but this order has emerged as a result of individual choices and not as a result of collective choice. The actions of individuals leading to the spontaneous market order were not motivated by the collective result of their actions but only by capturing individual private goods or benefits. In 
this case free-riding cannot exist.

However, the spontaneous market order is dependent on the existence of social rules of conduct. The market cannot work if the individuals do not follow certain social norms. The rules of conduct of individuals in the spontaneous market order are not identical with those social norms that serve as an institutionalized basis for the spontaneous market order. ${ }^{14}$ So if we want to explain the emergence and functioning of spontaneous market order, we also have to explain the emergence and functioning of those social norms that underpin this order. In his theory of socio-cultural evolution Hayek explains the emergence and functioning of social norms by extending the invisible-hand explanation to the sphere of social norms (See Van Den Hauwe 1998: 99).

The distinction between the rules of spontaneous order and the underlying social norms is about the distinction of two different forms of social integration. The spontaneous market order is built on the coordination of individual actions, the functioning of social norms is built on the cooperation of individual actors. As we saw earlier, coordination means the ordering of individual actions through an impersonal feedback mechanism. The price mechanism is such a mechanism of coordination. Cooperation means the ex ante mutual adjustment of individual expectations and actions through social norms. Respecting private ownership and observing private contracts are such social norms. The spontaneous market order as a result of social coordination is dependent upon the social norms demanding to respect private ownership and to observe private contracts from individuals. Hayek explains both the emergence of spontaneous order and that of social norms serving as a basis for this order as a result of evolutionary processes. However, can we explain coordination and cooperation with the same evolutionary theory if they are two different mechanisms of social integration?

The realm of social norms is different from that of the spontaneous order. Individuals may have an interest in following a social norm but they also have an interest to violate it, to free ride on it. Social norms invoke the paradox of collective action. Why would there be social norms if individuals have an interest in violating this norm? If it is rational for each individual to do so, the social norm will not come about. The analysis of social norms either has to solve or has to circumvent the paradox of collective action.

Hayek's theory circumvents the issue of free-riding by abandoning the principles of methodological individualism in the explanation of the emergence and functioning of social norms. Hayek answers the question why individuals would follow social norms if they had a private interest not to do this by pointing out that group-level rules of conduct generate a pressure on individuals not to deviate from the social norm in the form of tradition and group retaliation. ${ }^{15}$ The pressure of group-level norms eliminates the paradox of collective action. The selection of social norms is not the design of individuals but a spontaneous process that is taking place on the group-level, in the back of individuals. Those rules of conduct will survive that serve the survival of the group. This is how Hayek extends the evolutionary invisible-hand explanation to the emergence of social norms through the mobilization of a

\footnotetext{
${ }^{14}$ Vanberg (1994: 77), Hodgson (1993: 176) and Vromen (1995: 165) agree that it is important to make an analytical distinction between the rules of conduct of the market and the social norms that underlie and support the market.

15 "Hiba! Csak törzsdokumentumban használható.If deviant behaviour results in non-acceptance by the other members of the group, and observance of the rules is a condition of successful co-operation with them, an effective pressure for the preservation of an established set of rules will be maintained. Expulsion from the group is probably the earliest and most effective sanction or 'punishment' which secures conformity, first by mere actual elimination from the group of the individuals who do not conform while later, in higher stages of intellectual development, the fear of expulsion may act as a deterrent" (Hayek 1967: 78).
} 
holistic-functional argument. $^{16}$

To sum up: for Hayek the logic of aggregation works well for the analysis of the spontaneous market order. On the other hand the evolution of group-level rules of conduct cannot be explained by the aggregative mold of invisible hand explanation that remain within the confines of methodological individualism. The need to provide an evolutionary explanation of social rules of conduct (social norms) leads Hayek to introduce the concept of group-level selection into theory. Hayek transcends methodological individualism and connects the emergence of rules of conduct to a group-level selection process by utilizing functionalist arguments. Hayek thinks that one may have a comprehensive evolutionary theory both for market and social norms, that is both the spontaneous order and the social norms supporting it may be explained as the unintended consequences of individual actions, although not in the same way. The investigation of market may rely on the logic of aggregation, that of social norms cannot.

Against Hayek Vanberg and Buchanan argue in favor of a methodologically consistent theory that does not abandon the principles of methodological individualism. They also emphasize the importance of the analytical distinction between coordination and cooperation. On the basis of this distinction they criticize Hayek's theoretical solution, the extension of the invisible hand explanation on the emergence of social norms.

The spontaneous order tradition contains a certain ambiguity in its analytical approach to the rules and institutions issue, an ambiguity that results from the failure sufficiently to distinguish between two different kinds of interaction problems, namely, in the terminology of modern game theory, coordination problems and prisoner's dilemma problems. There is a tendency throughout this tradition - from David Hume over Carl Menger to F. A. Hayek - to argue as if the kind of explanation that applies to coordination-type rules can be generalized to other kinds of rules as well, including those of the prisoner's dilemma type. (Vanberg - Buchanan 1988: 143)

Vanberg and Buchanan point out that the emergence of social norms (group-level rules of conduct) assumes cooperation, the mutual adjustment of individual intentions before action, consequently the emergence and functioning of rules of conduct follow a different logic from that of the emergence and functioning of the market. The emergence and existence of social norms cannot be explained by the single logic of coordination (see also Haller 2000: 555 and Bianchi 1994: 248).

It should be kept in mind, though, that the spontaneous coordination within markets and the enforcement of the legal-institutional framework of markets are different issues. The notion of spontaneous market coordination can very well be combined with a more "constructivist" view on the institutional framework. (Vanberg Buchanan 1988: 154)

Therefore, both Menger and Hayek are wrong when they think that the logic of the

\footnotetext{
16 "[T]he standard argument against group selection based on the free-ride problem cuts no ice against Hayek's theory of cultural evolution, because he did not conceive group selection as a "solution" to collective action problems in the first place. In Hayek's approach, group selection explains why certain rules of behavior survived while others disappeared in terms of their contribution to the creation and maintenance of a viable social order. It does not explain why individuals conform to the norms that prevail in the group they belong to. The explanation for individual conformism is either the benefits of coordination (in the case of self-enforcing rules) or peer pressure and retaliation." (Andreozzi 2005: 235).
} 
explanation of the spontaneous order can be extended to the explanation of the emergence and functioning of social norms (Vanberg - Buchanan 1988: 144).

Vanberg and Buchanan disapprove Hayek's attempt to keep the issue of the emergence and functioning of social norms within the realm of evolutionary theory. For them the important theoretical question is how it is possible to preserve the principles of methodological individualism in the explanation of the emergence of social norms? They understand that the aggregate mold of invisible-hand explanation cannot be applied to the analysis of social norms, but they also want to avoid to use the functional mold of invisiblehand explanation. In other words, the theoretical solution for them is to abandon the invisiblehand explanation of social norms. In order to preserve the theoretical framework of methodological individualism in the investigation of social norms Vanberg and Buchanan propose to limit the application of evolutionary theory. From the position of Vanberg and Buchanan the research question to be asked will be the following: if following group-level rules of conduct did not directly benefit individuals, why would these rules be created by selfinterested individual actions? ${ }^{17}$ There may exist rules of conduct that create group-level advantages, but we can understand the emergence of these social norms only if we can explain "how group advantage translates into incentives for individuals to exhibit groupbeneficial but individually sacrificial behavior [...]" (Vanberg 2014: 53).

Answering this question Vanberg and Buchanan use the conceptual framework of constitutional economics. Relying on the theory of social contract constitutional economics offers an opportunity to remain within the confines of methodological individualism in the explanation of the emergence and survival of social norms. ${ }^{18}$ The basic proposition of constitutional economics is that we should distinguish between actions carried out by following rules of conduct and actions creating rules of conduct.

\begin{abstract}
Whether or not it is rational for persons to comply with rules that they constitutionally may agree on is a matter of contingent, factual circumstances and not of rationality per se. It depends on whether or not the constraints that persons face after the agreement - i.e. post-constitutionally - make it rational for them to comply with previously agreed on rules. There is, to be sure, a rational link between constitutional agreement and compliance, but it is of an indirect rather than a direct nature. [...] If it is rational for persons to agree on rules, it is rational for them to see to it that compliance is rational and, where necessary, to agree on some appropriate enforcement scheme, provided the costs of enforcement are warranted by the prospective cooperative gains (Vanberg - Buchanan 1988: 141-142).
\end{abstract}

From this distinction follows the conceptual difference of constitutional interest and action interest. Individuals may have a constitutional interest in choosing certain rules of conduct even if they suffer relative disadvantages from the functioning of those rules. These disadvantages may be balanced off by the benefits derived from the choice of them. These benefits would have been lost if individuals had chosen some other rules. This argument situates the issues of institutional change within the framework of individual rational choice. ${ }^{19}$ By connecting the emergence of rules of conduct to constitutional action related at

\footnotetext{
17 "While the general benefits that a moral order generates are quite obvious, it is far less obvious how rational pursuit of self-interest should induce the kind of conduct that such an order requires" (Vanberg - Buchanan 1988: 138).

${ }^{18}$ Similarly to Vanberg, Petsoulas also emphasizes the role of collective agreement in the emergence of rules of conduct that solve the paradox of collective action (Petsoulas 2001: 42).

${ }^{19}$ This theory implies the assumption that choosing institutions individuals are able to predict their beneficial effects. See Khalil (1996: 194).
} 
the same time to individual cost-benefit calculations the solution of constitutional economics clearly puts the paradox of collective action on the agenda. Why would rational individuals follow constitutionally accepted rules if they can free-ride on it? Why should I respect the rule of private property rights if I can gain from violating it?

There is a difference between the question of whether we like to respect rules of property and the question of whether we like to live in a society in which property rights are respected. A thief, by his actions, clearly indicates that he does not want to respect property. But, if he were made to choose between a society where property rights are enforced and one where no property rights are respected whatsoever, we can rest assured that he will opt for the first because it is bound to be the wealthier society. It is in this sense that we can distinguish between our action interests, i.e. our preferences over alternative courses of action that are open to us under given constraints, and our constitutional or rule interests, i.e. our preferences over alternative rule regimes under which we may come to live (Vanberg 2001: 65).

Vanberg thinks that the theory of constitutional economics is able to demonstrate that there exists a social mechanism that solves the issue of free-riding. ${ }^{20}$ In fact, this proposition may not solve but rather circumvent the paradox of collective action, just because it is based on the analytical separation of choices made about the introduction of alternative regimes of rules (constitutional level) and choices made within a given regime of rules (action level). On the constitutional level even would-be free riders will choose a rule they do not prefer and do not follow on the action-level. But if they do not follow the chosen rule on the action-level, the rule will not survive. The problem is that this proposition connects a hypothetical level of constitutional choice between rules to a real level of choice within rules. We cannot infer from a choice made under hypothetical conditions to a choice made under real conditions. If choices on both level were made under real conditions, free-riding would have an effect on choices both between and within rules. By putting the investigation of the emergence of rules of conduct into the hypothetical framework of social contract on the constitutional level this theory remains vulnerable to the paradox of collective action and assumes a constructivist, non-evolutionary character. ${ }^{21}$ The mechanism proposed by constitutional economists in order to solve the paradox of collective action seems to be more hypothetical than real.

Evolutionary theory does not infer from a hypothetical creation of constitutional rules to their application in reality. On the contrary, it relates the process of choice among social norms, that is conceived as a process of selection of rules of conduct, to choices made within the framework of rules of conduct, since the first process is mediated by the second one. If we deal with the emergence of socially accepted norms on the basis of the invisible-hand

\footnotetext{
20 "Hiba! Csak törzsdokumentumban használható. The fact that groups in which group-beneficial rules are followed provide a more attractive environment for their members cannot explain per se why individuals are willing to comply if it is costly for them. In order for such compliance to be individually advantageous there must be some mechanism at work that sufficiently compensates for the individual sacrifice and the explanatory task is to specify the mechanism by which this is achieved" (Vanberg 2014: 53).

${ }^{21}$ At the same time Vanberg and Buchanan (1988: 147) make an attempt to give a non-constructivist explanation of the emergence of social norms. They argue that the emergence of the norms of cooperation can be understood as the extension and spreading of reciprocal diadic relationships of individuals. At the starting point within the diadic relationship free riding can be controlled and excluded by the participating individuals. Then the success of reciprocal diadic relationships makes the norms of these relationships socially attractive. The weak point of this argument, as the authors themselves acknowledge, is related to the transition from the establishment of a diadic norm to a generalized social norm. How will the norms observed by individuals under the pressure of personal relatonships be enforced if these norms become universal non-personal social norms accepted by a great number of individuals?
} 
explanation, we do not have to assume that these rules are consciously designed by individual actions within the framework of a hypothetical social contract. For Hayek Vanberg's and Buchanan's theory on the emergence of rules of conduct that may support the spontaneous market order should prove to be a version of constructivism and cannot be accepted. ${ }^{22}$

However, Vanberg protests against the claim that the solution of constitutional economics about the emergence and functioning of social norms is a constructivist attempt. He fully accepts the Hayekian assumption of imperfect information, and in the explanation of the emergence of social norms he tries to reconcile the theory of social evolution with the notion of human design. In other words, Vanberg wants to remove the tension he finds in Hayek's theory of socio-cultural evolution by removing the holistic-functionalist argument that relies on the concept of group-level selection. Vanberg on the one hand wants to keep the explanation of the formation of social norms within the theoretical framework of methodological individualism and to link the emergence of these norms to the interests and incentives of individuals, on the other hand he wants to avoid the pitfalls of constructivism and reintroduce evolutionary theory into the explanation of social norms. The question is whether the elimination of the dualism of Hayek's methodology could also avoid to bring about new tensions in the theory of constitutional economics?

\section{Evolution versus rational constructivism}

Hayek, as we saw, assumes that the emergence of market and that of social norms supporting it follow the same logic, consequently they emerge spontaneously and not as a result of deliberate individual actions. From the position of methodological individualism only those rules of conduct will come into existence that are beneficial for the individuals who establish these norms. This requirement ties to specific conditions the successful selection of rules of conduct that would support social order. From this it follows that these social norms cannot emerge spontaneously. That is the reason why Vanberg accepts only a limited version of evolutionary theory. For him evolutionary theory should be made compatible with the principle of rational constructivism.

To the extent that it is defendable, the evolutionary argument is compatible with the rational, constructive component of his liberalism. And to the extent that it is not compatible with the latter, the evolutionary argument turns out to be problematic. (Vanberg 2001: 55)

Contrary to this position Hayek argues that the rules of conduct supporting and maintaining the spontaneous market order are the results of an evolutionary process of selection. With the theory of spontaneous, evolutionary process of group-level selection Hayek wants to explain why individual actions are to lead to the emergence and retention of rules of conduct that do not realize particular individual interests and therefore individuals do not intend to design and establish these rules. ${ }^{23}$ The evolutionary theory of social norms has to face the following

\footnotetext{
${ }^{22}$ Vanberg and Buchanan (1988: 142) know that Hayek explains the emergence of costitutional rules of conduct as the unintended consequences of individual actions, regardless of the constitutional preferences of individuals. 23 'Speaking of the 'twin ideas of spontaneous order and evolution,' he wants to emphasize the close connection between his evolutionary argument and his concept of spontaneous order. A spontaneous social order results from the interplay of actors who pursue their own interests within the confines of certain general rules of conduct. The general nature of the resulting order will critically depend on the nature of the general rules that govern the actors' behavior. In Hayek's terminology, the nature of the order of rules will determine the character of the resulting order of actions. Not just any order of rules will result in an order of actions with desirable properties. For a beneficial order to emerge, 'suitable' or 'appropriate' rules are required. This raises, of course,
} 
question: does the invisible hand explanation of social norms allow for the deliberate change of social institutions, the possibility of social reforms? $?^{24}$

Social institutions change due to intended and unintended consequences of individual actions. Although Hayek excludes the possibility of rational reform of the system of social institutions, he allows for a deliberate change, redesign of particular institutions, rules of conduct. Deliberate human action does not result in new social order but may improve the rules of a given social order.

At any one stage of our evolution, the system of values into which we are born supplies the ends which our reason must serve. This givenness of the value framework implies that, although we must always strive to improve our institutions, we can never aim to remake them as a whole, and that in our efforts to improve them we must take for granted much that we do not understand: We must always work inside a framework of both values and institutions which is not of our own making. It means in particular that we can never synthetically construct a new body of moral rules, or make our obedience of the known rules dependent on our comprehension of what depends on this obedience in the particular instance. (Hayek 1958: 236)

Hayek's theory of socio-cultural evolution allows for the deliberate formation of social institutions but only in a limited way that is predetermined by the framework of evolutionary theory. If Hayek allows the deliberate modification of the existing system of social norms, he also has to answer the question what is that normative criterion that may serve as a guideline for the intended changes? ${ }^{25}$

Since the conscious intervention into the system of rules affects abstract norms, about the function of which individuals are ignorant, the intervention must follow abstract and formal criteria. These criteria require compatibility with the system of rules and the universalism of the rule of law. The modifications of rules have to improve the universalism of the laws (Hayek 1973: 106; 1979: 167).

Vanberg reinterprets the relationship between spontaneous order and the social norms that serve as an institutional basis for this order by arguing that the functioning of spontaneous market order follows an evolutionary logic, but competition, the discovery processes of the market are dependent on those social norms that are the results of human design. The planning of institutions is not the opposite of spontaneous evolutionary processes, rather it is the condition of them. If Hayek asks whether the invisible-hand explanation of social norms allow for the deliberate change of social institutions, the possibility of social reforms, Vanberg asks whether the theory of conscious design of social

the question of how we may hope to find such rules, and it is in this context that Hayek advances his theory of cultural evolution, i.e. the notion of a spontaneous evolutionary process in which alternative rules are experimented with and in which, through trial and error, experience about which kinds of rules work well and which do not is accumulated" (Vanberg 2001: 58).

24 "If we accept that human societies are in large part the unintended outcomes of individual acts and that human actions have unlooked-for consequences, does that not also apply to the rules of social order? Perhaps the rules themselves are also the unintended consequences of other actions, and perhaps they emerged as part of a larger spontaneous order. But, if that is so, the very idea of designing the constitution of liberty becomes problematic. How can we design a system of rules to protect individual liberty when we cannot foresee the consequences of our schemes? On the other hand, if we cannot in some sense design the rules by which we live, can we ever hope to change them for the better?" (Vaughn 1999: 540-541; see also Rowland 1988: 222).

${ }^{25}$ Vanberg poses the question of normativity not only in relation to deliberate reforms of a given order but he extends it to the whole process of Hayekian evolution: "The question, therefore, remains: if he does suggest that cultural evolution tends to promote 'beneficial' institutions, what is the normative criterion that he employs?" (Vanberg 2001: 64). 
norms may integrate into itself the evolutionary concept of spontaneous selection among rules of conduct?

Understood as a conditional argument, Hayek's evolutionary account tells us that, on the one hand, we need to rely on competitive evolutionary processes as discovery procedures because we cannot know in advance what the best solutions to our problems may be, and that, on the other hand, we need to constrain evolutionary competition by a framework of appropriate rules in order to make it responsive to the interests of the persons involved. To the extent that the creation of such a framework requires deliberate legislative action, institutional design is not opposed to the role of spontaneous forces, but is a prerequisite for their beneficial working. (Vanberg 2001: 69)

Vanberg states that the assumption that evolutionary processes of spontaneous order can be deliberately limited by rules serving the interests of individuals does not necessarily mean that the emergence of these rules is not subject to the processes of evolutionary selection. By permitting the distinction of social processes subject to evolution and not subject to it, we would bring back the assumption of perfect information into theory. Vanberg, following Hayek, does not want to do this and makes the statement that the emergence of those social institutions that support the spontaneous order is the result of an evolutionary discovery process and competition.

[I]n order to make evolutionary competitive processes operate responsively to the interests of the individuals involved, we need to impose appropriate rule constraints. And as we cannot know in advance what the most appropriate constraints may be, we need to rely, on the level of rules as well, on competition as a discovery procedure. (Vanberg 2001: 75).

In this way the assumption about the role of human design in social change can be made compatible with the concept of social evolution, proposes Vanberg. Social norms are designed by individuals, but the planning of social institutions is subject to the selective processes of social evolution. Institutions may be designed, the processes that select among them cannot. There is no contradiction between the concepts of spontaneous order, institutional design and evolutionary competition of social institutions, argues Vanberg. ${ }^{26}$ So far so good. However, Vanberg's proposition for the synthesis between constitutional economics and evolutionary theory cannot eliminate a tension in theory. How can the constitutional choices made under the hypothetical conditions of social contract be linked to choices made under real, existing conditions within an evolutionary theory that cannot think in terms of hypothetical conditions only in terms of historically emerging conditions? Hayek's evolutionary rationalism ${ }^{27}$ does not have to deal with this tension, since it does not intend to integrate a hypothetical process of rule creation into the evolutionary theory of the real processes of selection of rules of conduct.

\section{Conclusion}

\footnotetext{
26 “Similar to his view on market competition, Hayek's view on cultural evolution is based on the argument that in the realm of rules, no less than in other areas of problem-solving efforts, we need to rely on competition as $a$ discovery procedure. And his argument against 'constructivist rationalism' in the realm of rules and institutions is not meant as an objection against institutional design per se, but against excessive claims that ignore the limits of our knowledge and reason." (Vanberg 2001: 71; see also Schubert 2004: 18).

${ }^{27}$ The term is coined by Vanberg (2001: 71).
} 
Hayek's theory of socio-cultural evolution is the generalization of his theory of spontaneous market order. Hayek explains the emergence of market and that of social institutions serving as a basis for market order with the same logic. This logic interprets the emergence and survival of the spontaneous order and group-level rules of conduct as an unintended consequence of individual actions. At the same time the extension of invisible-hand explanation to the analysis of the emergence and retention of social norms also introduces a distinction into the theory, the aggregate mold of explanation is supplemented by holisticfunctionalist arguments.

The aggregate mold of invisible-hand explanation based on methodological individualism works well for the case of spontaneous market order, we can understand why self-interested individuals bring into existence social mechanisms like money and the price system, although they do not intend to do so. The private motivations of individuals sufficiently explain the emergence and existence of market order. At the same time Hayek sees that the market is dependent on the existence of certain social norms like the respect of private property rights and contractual obligations. Hayek also sees that the emergence and existence of these rules of conduct cannot be explained by the aggregate mold of invisiblehand explanation, since complying with group-level rules of conduct assumes collective action, the mutual adjustment of individual intentions of actors. As opposed to the emergence of spontaneous market order the formation of social norms cannot be derived from the actions of self-interested individuals, because individuals bring about social norms the violation of which is also in their interests. The explanation of the emergence and existence of social norms has to cope with the paradox of collective action. Hayek solves this problem by the application of holistic-functionalist explanations that deny methodological individualism. For Hayek, in order to uphold the validity of the invisible-hand explanation for the analysis of social rules of conduct, we have to reject the application of the aggregate mold of explanation based on methodological individualism. In order to extend the evolutionary theory to the analysis of social norms we have to resort to arguments about the group-level selection of rules of conduct. To sum up, Hayek's dilemma is how to preserve the evolutionary explanation but to abandon the aggregate mold of invisible-hand explanation without applying constructivist arguments in the theory of social norms? For him the solution is to give up methodological individualism and to resort to functionalist-evolutionary arguments.

Those who want to remain within the theoretical framework of methodological individualism to explain the emergence and existence of social norms have to rule out the application of evolutionary-functionalist arguments. They say that the functionalist explanation cannot satisfactorily answer the question why individuals would follow rules of conduct that are advantageous for the group but do not bring individual gains for them. The functionalist-evolutionary explanation cannot cope with the paradox of collective action, with the free-riding of individuals, it does not deal with the issue how individual motivations triggering individual actions may lead to the emergence and existence of social rules of conduct. The theory of social norms based on methodological individualism has to cope with the problem whether it is possible to avoid the trap of holistic functionalism in the explanation of the emergence of social norms if we understood that group-level rules of conduct cannot be explained by relying on the logic of aggregation of the outcomes of individual actions. A theory like this is possible, but the rejection of both the aggregate and functionalist molds of explanations means the rejection of the invisible-hand explanation in general. In other words, the only chance to preserve the principles of methodological individualism in the explanation of the emergence of group-level rules of conduct is to limit the scope of evolutionary theory and to complement it with constructivist arguments. That is 
Vanberg's proposition. Consequently, Vanberg has to face the dilemma that in order to preserve the validity of methodological individualism in the analysis of the emergence and existence of social norms one has to give up the aggregate mold of explanation and at the same time to avoid the application of functionalist-evolutionary arguments. In order to defend the exclusivity of methodological individualism the constitutionalist economist has to limit the application of evolutionary explanation.

Hayek's theory of socio-cultural evolution does not solve the problem of free-riding, rather it circumvents it. Hayek explains the emergence and the existence of group-level rules of conduct by a group-level process of selection: a rule may come into existence if it serves the survival of the group. Consequently, he does not relate the emergence and existence of social norms to the effects of individual incentives and interests. Why would individuals observe rules that they did not create to serve their individual interests? The answer is the existence of pressure of group-level rules on individuals. Hayek refers to tradition, the fear from ostracism. This explanation does not have to deal with the problem of free-riding, since group pressure eliminates it.

Constitutional economists offer an alternative theory: on the basis of methodological individualism they want to explain the emergence and existence of rules of conduct as a consequence of deliberate individual actions. Individuals establish rules because it is beneficial for them. Buchanan and Vanberg argue that rules of conduct emerge as a result of collective action. Consequently, this theory has to deal with the paradox of collective action. However, the solution offered by constitutional economics remains problematic because it solves the problems of individual incentives by relating individual actions within real existing conditions to individual actions within the hypothetical conditions of constitutional choice. However, we cannot jump from the acceptance of social norms under the hypothetical conditions of social contract to the acceptance of these norms under real, in fact existing, conditions. Buchanan's and Vanberg's theory seems to remain in want of a solution of the free-riding issue.

It is true that Hayek's theory of socio-cultural evolution does not consistently remain within the theoretical framework of methodological individualism. However, this "inconsistency" seems to be productive, it contributes to our understanding of socio-cultural evolution. There is no logical contradiction in the addition of a functional-evolutionary mold to the aggregate mold of invisible-hand explanation, since these different arguments refer to different aspects of the subject of the theory. The logic of aggregation is related to the spontaneous market order, the functionalist logic is related to the system of rules of conduct. The system of rules of conduct is not identical with the spontaneous market order, the former serves as a necessary social environment for the latter. ${ }^{28}$ Hayek's theory of socio-cultural evolution is an example for applying a heterodox methodology that integrates different methodological positions without running into contradictions of logic. Since in Hayek's theory the two different methodologies thematize different aspects of institutional change, the explanation built on methodological individualism and the explanation relying on holisticfunctionalist arguments do not crowd out, rather they complement each other.

\section{References}

Agassi, J. (1975): Institutional individualism. The British Journal of Sociology 26(2): 144155.

\footnotetext{
${ }^{28}$ Berger and Offe (1982: 523), Agassi (1975), Radnitzky (1999: 482), and Caldwell (2004: 356) also argue that methodological individualism and the functional-evolutionary explanation can be made compatible.
} 
Andreozzi, L. (2005): Hayek Reads the Literature on the Emergence of Norms. Constitutional Political Economy 16(3): 227-247.

Angner, E. (2001): Did Hayek Commit the Naturalistic Fallacy? Paper presented at the 2001 Summer Institute for the Preservation of the Study of History of Economics in Economics at George Mason University.

Angner, E. (2002): The history of Hayek's theory of cultural evolution. Studies in History and Philosophy of Biological and Biomedical Sciences 33(4): 695-718.

Beaulier, S. A. - Prychitko, D. L. (2006): Disagreement over the emergence of private property rights: alternative meanings, alternative explanations. Review of Austrian Economics 19(1): 47-68.

Berger, J. - Offe, C. (1982): Functionalism vs. Rational Choice? Some Questions concerning the Rationality of Choosing One or the Other. Theory and Society 11(4): 521-526.

Bianchi, M. (1994): Hayek's Spontaneous Order: The 'Correct' Versus the 'Corrigible' Society. In: Birner, J. and van Zijp, R. (eds.): Hayek, Co-Ordination and Evolution. His Legacy in Philosophy, Politics, Economics and the History of Ideas. London and New York: Routledge, pp. 232-254.

Caldwell, B. (2001): Hodgson on Hayek: A Critique. Cambridge Journal of Economics 25(4): 539-553.

Caldwell, B. (2004): Hayek's Challenge: An Intellectual Biography of F.A. Hayek. Chicago: University of Chicago Press

Davis, J. B. (1989): Smith's Invisible Hand and Hegel's Cunning of Reason. International Journal of Social Economics 16(6): 50-66.

Denis, A. M. P. (2001): Collective and Individual Rationality: Some Episodes in the History of Economic Thought. PhD thesis, City University, London, Department of Economics, School of Social and Human Sciences.

Denis, A. (2002): Was Hayek a Panglossian Evolutionary Theorist? A Reply to Whitman. Constitutional Political Economy 13(3): 275- 285.

Gauss, G. F. (2006): Hayek on the Evolution of Society and Mind. In: Feser, E. (ed.): The Cambridge Companion to Hayek. Cambridge: Cambridge University Press, pp. 232258

Gedeon, P. (2001): Gazdaságtan és evolúció [Economics and Evolution]. In: Pál, E. (ed.): Útközben. Tanulmányok a társadalomtudományok köréböl Somlai Péter 60. születésnapjára. Budapest: Új Mandátum Könyvkiadó, pp. 228-243.

Gedeon, P. (2004): Marx és Menger a pénz evolúciójáról [Marx and Menger on the evolution of money]. Társadalom és gazdaság 26(1): 57-70.

Gray, J. (1984): Hayek on Liberty. Oxford: Blackwell

Haller, M. (2000): Carl Menger's Theory of Invisible-Hand Explanations. Social Science Information 39(4): 529-565.

Hayek, F. A. (1948): Individualism and economic order. Chicago: University of Chicago Press

Hayek, F. A. (1958): Freedom, Reason, and Tradition. Ethics 68(4): 229-245.

Hayek, F. A. (1967): Studies in Philosophy, Politics and Economics. London: Routledge \& Kegan Paul

Hayek, F. A. (1973): Law, Legislation and Liberty, Vol. 1: Rules and Order. London: Routledge \& Kegan Paul

Hayek, F. A. (1976): Law, Legislation and Liberty, Vol. 2: The Mirage of Social Justice. London: Routledge \& Kegan Paul

Hayek, F. A. (1978): New Studies in Philosophy, Politics, Economics and the History of Ideas. London: Routledge \& Kegan Paul 
Hayek, F. A. (1979): Law, Legislation and Liberty, Vol. 3: The Political Order of a Free People. London: Routledge \& Kegan Paul

Hayek, F. A. (1984): The Origin and Effect of Our Morals: A Problem for Science. In: Nishiyama, C. - Leube, K. R. (eds.): The Essence of Hayek. Stanford: Hoover Institution Press, pp. 318-330.

Heath, E. (1992): Rules, Function, and the Invisible Hand: An Interpretation of Hayek's Social Theory. Philosophy of the Social Sciences 22 (1):28-45.

Hodgson, G. M. (1993): Economics and Evolution. Bringing Life Back into Economics. Cambridge: Polity Press

Kapás, J. (2002): Piacszerü vállalat és vállalatszerü piac [Market-like firm and firm-like market]. Közgazdasági Szemle 49(4): 320-333.

Kapás, J. (2003): A piac mint intézmény - szélesebb perspektívában [The market as an institution - A broader perspective]. Közgazdasági Szemle 50(12): 1076-1094.

Khalil, E. L. (1996): Friedrich Hayek's Darwinian Theory of Evolution of Institutions: Two Problems. Australian Economic Papers 35(66): 183-201.

Madarász, A. (2005): Friedrich August von Hayek: 1899-1992. In: Bekker, Z. (ed.): Közgazdasági Nobel-díjasok 1969-2004. Budapest: KJK-Kerszöv, pp. 151-168.

Madarász, A. (2014): A láthatatlan kéz - szemelvények egy metafora történetéböl [The invisible hand - excerpts from the history of a metaphor]. Közgazdasági Szemle 61(78): 801-844. o.

Nafissi, M. R. (2000): The Paradox of Principles: The Dialectics of Hayek's Liberalism. Economy and Society 29(2): 207-238.

O'Brien, D. P. (1994): Hayek as an Intellectual Historian. In: Birner, J. - van Zijp, R. (eds.): Hayek, Coordination and Evolution. London: Routledge, pp. 343-374.

Olson, M. (1971): The Logic of Collective Action: Public Goods and the Theory of Groups. Cambridge, Mass.: Harvard University Press

Orthmayr, I. (2002): Polányi Mihály és a társadalmi evolúció elmélete [Mihály Polányi and the theory of social evolution]. Polanyiana, 1-2.: 89-115.

Orthmayr, I. (2004): A társadalmi normák döntéselméleti és evolúciós magyarázata [A decision theory and evolutional explanation of social norms]. Szociológiai Szemle 14(3): 3-22.

Petsoulas, C. (2001): Hayek's Liberalism and its Origins. His Idea of Spontaneous Order and the Scottish Enlightenment. London: Routledge

Radnitzky,G. (1999): An Economic Theory of the Rise of Civilization and Its Policy Implications: Hayek's Account Generalized. In: Boettke, P. J. - Farrant, A. - Ransom, G. - Salgado, G. (eds.): The Legacy of Friedrich von Hayek. Volume I: Politics. Cheltenham, UK: Edward Elgar, pp. 477-519.

Rowland, B. M. (1988): Beyond Hayek's Pessimism: Reason, Tradition and Bounded Constructivist Rationalism. British Journal of Political Science 18(2): 221-241.

Schubert, C. (2004): Hayek and the Evolution of Designed Institutions:a Critical Assessment. Papers on Economics and Evolution No. 0411, Max Planck Institute for Evolutionary Economics Group, MPI Jena

Sugden, R. (1989): Spontaneous Order. The Journal of Economic Perspectives 3(4): 85-97.

Ullmann-Margalit, E. (1997): The Invisible Hand and the Cunning of Reason. Social Research 64(2): 181-197.

Ullmann-Margalit, E. (1978): Invisible-Hand Explanations. Synthese 39(2): 263-291.

Van Den Hauwe, L. (1998): Evolution and the Production of Rules. Some Preliminary Remarks. European Journal of Law and Economics 5(1): 81-117.

Vanberg, V. J. (1994): Spontaneous Market Order and Social Rules. A Critical Examination 
of F. A. Hayek's Theory of Cultural Evolution. In: Vanberg, V. J.: Rules and Choice in Economics. London: Routledge, pp. 77-94.

Vanberg, V. J. (2001): The Constitution of Markets. Essays in Political Economy. London: Routledge

Vanberg, V. J. (2014): Darwinian Paradigm, Cultural Evolution and Human Purposes: On F.A. Hayek's Evolutionary View of the Market. Journal of Evolutionary Economics 24(1): 35-57

Vanberg, V.J. - Buchanan J. M. (1988): Rational Choice and Moral Order. Analyse und Kritik 10(2): 138-160.

Vaughn, K. I. (1999): The Constitution of Liberty from an Evolutionary Perspective. In: Boettke, P. J. - Farrant, A. - Ransom, G. - Salgado, G. (eds.): The Legacy of Friedrich von Hayek.Volume I: Politics. Cheltenham, UK: Edward Elgar, pp. 537-560.

Vromen, J. J. (1995): Economic Evolution. An Enquiry into the Foundations of New Institutional Economics. London: Routledge

Witt, U. (1994): The Theory Of Societal Evolution: Hayek's Unfinished Legacy. In: Birner, J. - van Zijp, R. (eds.): Hayek, Co-ordination and Evolution. His Legacy in Philosophy, Politics, Economics and the History of Ideas. London: Routledge, pp. 178-189. 